\title{
Juridical and Sociological Implications of Wrong Arrest (Wrong Procedure) Against the Defendant in the Criminal Justice System Linked to the Rights of Citizens and the Protection of Human Rights
}

\begin{abstract}
H. Darmadi Djufri. SH., M. H*
The writer is a Law Doctoral Program Student at Borobudur University, Jakarta

Abstract

The legal protection given to the accused is an indication of wrongful arrest is treated the same as the other defendants that is given their rights under the Criminal Procedure Code. This was done because it prioritized legal certainty, namely by the existence of an innocent verdict from the court, the decision could be used as the basis for the right to file compensation claims. Legal protection related to the defendant's rights has been regulated in international conventions and legislation, but its implementation needs to be emphasized, so that investigators in carrying out their duties are more professional.

Judicially, and sociologically, for citizens who have experienced wrongful arrests (wrong procedures) their rights will still be protected, as stipulated in the ICCPR (International Convenant on Civil and Political Rights), in which case Indonesia has ratified and has been regulated in Criminal Procedure Code, and strengthened by subsequent legislation.
\end{abstract}

Keywords: Legal Protection, Implementation of Law Enforcement, Human Rights

DOI: $10.7176 / \mathrm{JLPG} / 90-12$

Publication date:October $31^{\text {st }} 2019$

\section{A. Introduction}

In addition to the law (the Constitution, Laws and other laws and regulations) as an application of democratic theory about general elections chosen by a country, the relationship between law and democracy can also be seen in terms of rule of law or nomocracy (rule based on law) as one of the pillar of democracy. There are at least 11 (eleven) elements or pillars of democracy, namely: ${ }^{1}$

1. Rights and freedoms of citizens, such as the right to self-determination, the right to vote and be elected, the right to express opinions, the right to associate, freedom of religion, the right to preserve cultural identity, economic freedom, and human rights in general . Such rights and freedoms will undoubtedly give birth to not only the diversity of society, but also various forms of differences between individual citizens. Although there are differences between citizens and between groups in society, they all have an equal position as citizens ('we are different but we are equal citizens') in law and government. The principle of populist or people's sovereignty which means 'government from, by and for the people,' comes from this first pillar;

2. Agreements of various national elements that are compounded to not only become one nation, but also form a nation-state. This agreement to live together as a nation was achieved based on at least three principles, namely: the identity and uniqueness of each element respected (we are different), recognition of equal status among citizens (we are equal), and an awareness that they all are brothers of the Nation and of the Motherland (we are brothers and sisters). An agreement forms a country and the willingness to become a citizen is based on an agreement on the purpose, form and composition of the state. 'Protecting all Indonesian people and all Indonesian bloodshed, promoting public welfare, educating the nation's life, and helping to maintain world peace ...' for example, is the goal of the Republic of Indonesia (state structure) of the Republic of Indonesia. The Republic of Indonesia established must protect all nations (all elements of the nation, both ethnic groups and religious groups, both nominally minority and majority), and protect the entire Indonesian blood spill (all regions of Indonesia that are near government centers and remote ones). The purpose, form and composition of the state, the system of government, the distribution of power and so forth are regulated in the Constitution. In short, nationality (nation state) is an important fundamental of the democratic political system. Nationhood is necessary for democratic political systems to function but it is not sufficient;

3. General elections are held based on direct by voters, general suffrage, free, secret, honest and fair, transparent and accountable which are held periodically and in an orderly manner for electing state legislators and executive institutions at both national and regional levels. Population, area size, and

${ }^{1}$ Ramlan Surbakti, Demokrasi, Hukum, Dan Reformasi Peradilan, Komisi Yudisial Republik Indonesia, Jakarta, 2014, p. 3 
complexity of the problems faced by a nation-state are a number of factors which among others cause direct government of people (direct democracy) to be impossible, at least not possible for all types of duties and authority of the state. This then gave birth to the concept of representative democracy, namely government by people chosen by the people. The second element is the implementation of representative democracy. However, only elections held on the basis of direct, general, free, secret, honest and fair, transparent and accountable principles can be categorized as democratic elections. The following phrase reveals this second pillar: You can have elections without democracy but you cannot have democracy without election.

4. Balanced and mutual checks and checks (checks and balances) between the legislative, executive, judiciary, auditing of state finances, and various other state institutions which carry out special and complementary tasks and authorities of the state (auxiliaries state), such as the Central Bank, and the General Election Commission. Apart from the form of government adopted by a democratic country, included in this third element is a stable and effective government (parliamentary or presidential government that is stable and effective), and an independent judiciary. The balanced division of power and mutual checks between various state institutions is intended not only so that representative institutions make laws in accordance with the constitution and the will of the people but also that government is held effectively and enforcement of laws can be enforced.

5. Rule of Law which at least contains four forms of application: (a) all citizens are at the same time in the law (equality before the law), (b) the implementation of all duties and authorities of the state (as stated in the fourth element) is regulated and implemented based on laws that have legal certainty, (c) constitutionalism, and (d) due process of law. These four forms of application will be further explained below.

6. The party system that is able to make the system of government, the system of political representation, and the political system of democracy in general functional for the people as holders of sovereignty in accordance with the characteristics of the nation and state concerned, such as a party system of simple pluralism, moderate pluralism or extreme pluralism. Political parties as a forum for people's political participation are not only the entry point for almost all public positions, or political party is the gateway for public offices, but also the political representation of the people in the process of making and implementing public policies. "Political parties and party systems are necessary but not sufficient for democratic political systems".

7. The system of political representation as a form of representative democracy is not only able to realize the voice of the people in legislation, budgets, and oversight of the implementation of legislation and budgets, but also able to work in synergy with executive institutions. The system of political representation adopted may be unicameral or bicameral, emphasizing "representativeness" or accountability, and more accentuating representation of ideas, representation by the presence or descriptive representation, or substantive representation. . This pillar gave birth to a legislative body that would make laws containing the regulation of the rights and freedoms of citizens and state institutions, arrangements regarding the burdens to be borne by citizens and private legal entities and sources of state revenue in general (revenue budget), and arrangements regarding various types of benefits that can be used by the people (budget). In a democracy, laws must be made by those who are elected by the people through democratic elections to be people's representatives. The duties and authorities of this legislation cannot be delegated to other parties who do not have a mandate from the people. The duties and authority of the executive body are derived from the product of the legislation, namely implementing the law, the duties and authority of the judiciary also come from the product of the legislation, namely enforcing the implementation of the law.

8. The system of representation of interests as an expression of the implementation of the right of association, the right to express opinions, and the right of political participation of citizens in general who are not only independent in forming and managing the forum they form, but also in formulating and fighting for their interests either through political parties or directly to legislative and / or executive institutions. Such a representative system of interests might adopt a pluralism system or a societal corporatism system. Another expression of the system of representation of interests such as this is civil society organizations (civil society organizations) which are not only independent but also functional in interacting with the state (state) and market society (economic society).

9. Regional autonomy and regional government systems that guarantee the implementation of governance at the local level by local residents or their representatives in accordance with the characteristics (local aspirations, local knowledge, local genius) of the local community so that they are not only able to maintain local identity, but also realize the welfare of local residents . The 
will to regulate and manage local interests, at least for some areas of life, seems to be a global will or demand regardless of whether the country's territory is small or large, an archipelagic or continental state, and whether the composition of a state is embraced by a federation or a unit. Regional autonomy is not only seen in the presence of DPRD and Regional Heads in regulating and managing some of the government affairs that are left to the autonomous regions, but especially the involvement of local residents in the process of making and implementing decisions concerning regional interests.

10. A competitive media system but with objective (factual) and balanced coverage (covers all sides) is the ninth pillar. This pillar is often described as the fourth power after the legislature, executive, and judiciary to illustrate the importance of both the communicator function carried by the mass media (delivering news from various elements of society to all elements of the country, and vice versa) as well as the critical and constructive functions of the mass media. But not all press systems can become pillars of democracy. The press system which is the pillar of democracy is a media system that is not monopolistic (not controlled by a handful of people but owned and managed by many parties independently and professionally), covers and delivers news factually, and covers and preaches all parties.

11. The process of carrying out all the tasks and authorities of the state takes place in a transparent and accountable manner. This means that all state administrators (who carry out the duties and authorities of the state) are obliged to explain what is done and what is not done that is related to their field of work whether requested or not requested by various elements in society. The principle of transparency arises from the right of citizens to get information from every state organizer. In addition, each state organizer is responsible for what is done and what is not done politically or legally, both horizontally and vertically. Political accountability does not cause a state official to go to jail if his accountability is not accepted by the public but the public official has two choices for taking responsibility for his actions:

a. admit wrongdoing and express an apology directly and openly to the public with a promise not to repeat the same act, or,

b. admit mistakes, resign from his position, and submit an apology directly and openly to the public. Legal accountability through a process of law enforcement (investigation, prosecution and trial), if found guilty by the court, will undoubtedly cause a state administrator to be imprisoned.

12. Culture of democracy, such as pluralism (we are different but we are equal and brothers and sisters), multi-culturalism, tolerance, cooperation and compromise will be formed if the ten pillars above have been implemented as an institutionalized. The willingness to accept defeat in elections (and congratulate the winner and the promise to support the winner) to one party and the willingness to respect the losing party (because the losing party also has the support of the people) to the other party, is also a manifestation of democratic culture. The willingness to compromise and cooperate with other parties to realize shared interests is a form of democratic culture, while maintaining one's own views and interests rigidly without regard to the views and interests of other parties with all the consequences is a form of authoritarian culture.

The practice of judicial wrongful arrests in Indonesia is not new, this often happens in the world of justice which claims to be a state of law (rechtstaat). Many innocent people are arrested, detained, and sentenced to prison. Some cases that have occurred, for example: ${ }^{1}$ Sengkon and Karta who had to spend time in prison, each for 7 (seven) years and 12 (twelve) years in prison for being convicted of murder crimes, then a husband and wife in Gorontalo who were forced to languish in prison because convicted of murdering their daughter, but apparently their daughter is still alive. The same thing happened to Budi Harjono, a young man in Bekasi who was suspected of killing his father and abusing his biological mother, but it was also not proven. There were also cases of persecution that resulted in the death of Bernas Daily journalist Fuad Muhammad Safrudin alias Udin, the police then arrested Dwi Sumaji alias Iwik as a suspect, even though he did not have sufficient evidence, so he was finally sentenced in the Bantul District Court. ${ }^{2}$

A number of the cases above indicate the actions of the police who fabricated the information of the suspect in making the Official Report of the Examination, namely the investigation was carried out with pressure or intimidation, so that the person was forced to admit the Official Report of the Investigation. The action shows that, in the investigation process to obtain a statement from the suspect, there are still investigators who use

\footnotetext{
${ }^{11}$ Http.co.id.,Salah Tangkap di Indonesia, Ironis Penegakan Hukum Di Peradilan Yang Sesat,.diakses pada tanggal 10 Januari 2019
}

${ }^{2}$ I Wayan Gendo Suardana, Peradilan Sesat dan Ironi Kondisi Hukum Indonesia, http://gendovara.blogdetik.com, diakses tanggal 03 Desember 2018, pukul $12.30 \mathrm{WIB}$. 
physical pressure and intimidation, so that what is stated in the Minutes of Examination is no longer pure and only to meet the target of the police. ${ }^{1}$

A series of cases of wrongful arrests that have occurred have shown the poor performance of law enforcement officers, because there is an error in the criminal justice system. One of the causes of the bad reputation is the poor performance of law enforcement officers, such as putting pressure on suspects. As a result of the poor performance of law enforcement is the decision taken by both the police, prosecutors and the court sometimes only provide bureaucratic justice that only applies the Act alone. ${ }^{2}$

There are many violations committed by law enforcers against suspects and defendants, for example the right of suspects to be accompanied and defended by legal advisors. This situation in practice tends to be ignored by law enforcers, even though these rights must be given to suspects or defendants. This right is an obligation of law enforcers to provide, so that the interests and rights of suspects and defendants can be protected as intended in Article 56 paragraph (1) of the Criminal Procedure Code. ${ }^{3}$

In contrast to the case of the defendant Maman Sugianto alias Sugik, even though the real culprit had been arrested, the trial that took place at the Jombang District Court continued. The judicial process cannot be stopped in the middle of the examination process, because the public prosecutor and the judge hears a case based on the Minutes of Examination received from the investigator. This means that neither the public prosecutor nor the judge had the initiative to try to consider new evidence in the form of a copy of the results of the deoxyribonucleic acid (DNA) test and the revocation of the BAP by the witness. The DNA test results contained the identity of the body of the victim who was indicted by the public prosecutor against the defendant. The situation will be different if the identification of the victim's body and the information of the accused witness has been known since the beginning of the investigation. Although there is new evidence that is a copy of the DNA test results and the revocation of witness statements in the BAP, the trial must continue based on the applicable stages in accordance with the rules in the hearing. It is at this stage that the role of judges is needed in handling these issues, because the facts show that the trial process cannot be stopped.

\section{B. Problem Formulation}

Based on what has been described in the background above, it attracts the interest of the writer to examine it more deeply and try to find answers to the problems that the writer raised, where the main problem that needs to be examined is why in the trial of the case of wrongful arrest (in this case the position as a defendant) law enforcement officers continue the judicial process as they should. In connection with the main problem, the principles that need to be questioned in this study are as follows:

1. How is the legal protection of the accused wrongly arrested according to positive Indonesian law and human rights?

2. What are the legal and sociological implications of the process and procedure of wrongful arrest in misleading criminal justice in Indonesia?

C.

\section{Research Methods}

This research is a descriptive study. Explorative research aims to deepen the knowledge of a particular phenomenon to get new ideas about a phenomenon. Generally carried out on knowledge that is still new, not much information about the problem under study or even none at all. Descriptive research aims to describe accurately the characteristics of an individual, a particular condition, symptom or group, or to determine the spread of a symptom or determine the presence or absence of relationships between other symptoms in society. While explanatory research, aims to test certain hypotheses whether there is a causal relationship between the various variables studied. Thus this research can only be done, if the information of the problem under investigation is sufficient, meaning that there have been several specific theories and there have been various empirical studies that have tested certain hypotheses. Literature research data is obtained from primary legal materials in the form of laws and regulations, secondary legal materials in the form of finished documents or publications such as journals and court rulings, and tertiary legal materials in the form of legal dictionaries, English-Indonesian dictionaries and large Indonesian dictionaries. While the field research data were obtained from interviews with interviewees based on questions and answers based on interview guides that had been prepared and had been prepared previously.

\footnotetext{
${ }^{1}$ Ibid.

${ }^{2}$ Satjipto Raharjo, Sosiologi Pembangunan Peradilan Bersih dan Berwibawa, Makalah pada seminar Reformasi Sistem Peradilan (Menanggulangi Mafia Peradilan) FH Undip Semarang, 1999, 6 Maret, hlm. 10-11. Lihat pula Agus Raharjo, Mediasi Sebagai Basis Dalam Penyelesaian Perkara Pidana, Jurnal Mimbar Hukum, Vol. 20 No. 1, FH UGM, Yogyakarta, Februari 2008 , p. 91.

${ }^{3}$ M. Sofyan Lubis dan M. Haryanto, Pelanggaran Miranda Rule dalam Praktek Peradilan di Indonesia, Juxtapose, Yogyakarta, 2008, p. 4.
} 


\section{Results and Discussion}

\section{Legal Protection Against Defendants of Misdirected (Wrong Procedures) in the Criminal Justice} Process

Etymologically, wrong means deviating from what it should be. ${ }^{1}$ While catching berari find. Arrest is an act of the investigator in the form of a temporary restraint of the freedom of the suspect or defendant if there is sufficient evidence for the purpose of the investigation or prosecution and / or justice in the case and according to the method provided for in the Law.

Arrest in other words is a temporary restraint of the freedom of the suspect or defendant, in the interests of investigation and prosecution, but must be carried out in the manner prescribed in the Criminal Procedure Code. An arrest can only be carried out by an investigator if a person is "strongly suspected of committing a crime and the allegation is supported by sufficient preliminary evidence". What is meant by sufficient preliminary evidence is preliminary evidence to suspect the existence of a criminal offense. In this case it shows that the arrest warrant cannot be carried out arbitrarily, but is aimed at those who have actually committed a crime. Yahya Harahap disagrees with the existence of the word beginning, so that it becomes "strongly suspected of committing a crime and the allegation is supported by sufficient evidence" because the initial word creates uncertainty in legal practice. ${ }^{2}$

A suspect is a person who because of his actions or circumstances, based on preliminary evidence, should be suspected as a criminal (Article 1 point 14 of the Criminal Procedure Code). Whereas the defendant is a suspect who was prosecuted, examined and tried in court (Article 1 point 15 of the Criminal Procedure Code). Thus, the understanding of suspects and defendants is a designation or status for the perpetrators of criminal acts according to the level or stage in the examination. So the implications that must be considered for the person are as follows: a. Must be investigated, investigated, and examined by the investigator; $b$. Must be prosecuted and examined before a court hearing by the public prosecutor and judge; and c. If necessary, forceful measures can be taken in the form of arrests, detentions, searches and seizures of objects in accordance with the manner prescribed by law. There is no explicit definition of wrongful arrest in the Criminal Procedure Code, but wrongful arrest is an implicit word in the Criminal Procedure Code: "A suspect, defendant or convicted person has the right to claim compensation for being arrested, detained, prosecuted and tried or subject to other actions, without reason based on the Law or because of "a mistake about the person" or the law applied ". Based on these provisions, it can be concluded that the mistake about the person here is not because of an error regarding the object being charged or error in persona, but a mistake regarding the accused or the person arrested. So there are several stages regarding wrongful arrests or errors regarding the person arrested, namely: 1. Wrongful arrest while still under investigation, i.e. after the status has been raised from a witness to a suspect and with alibi and sufficient evidence, it turns out that the evidence does not lead to the suspect. On this basis, at this stage there is no need to proceed with the next process; 2. Wrongful arrest when in court proceedings, i.e. in the trial process, it was discovered that the defendant was not involved in a crime at all; and 3. Incorrect arrest when undergoing a crime (for those who have received a permanent decision), i.e. found new evidence that leads to a person's evidence against a criminal act while undergoing a criminal period. What is meant by the issue of upholding the rights of suspects or defendants includes but is not limited to: ${ }^{3}$

a. Ignorance of suspects and defendants of their rights protected by law and law;

b. Law enforcement officials do not disclose information regarding the rights of suspects or defendants, whether intentional or not;

c. There are no explicit provisions governing the legal consequences if the rights of the suspect or defendant are not notified or violated;

d. The role of legal advisors in facultative and passive preliminary hearings.

Regarding the understanding of one's rights is very much dependent on many factors. Among these factors are low levels of education, profession or occupation and social and cultural background. This will be even worse with the state of the soul of someone who is suspected of being involved in criminal acts, so that the suspect in a state of mind is not clear and tends to surrender.

According to applicable law, law enforcement officials are obliged to notify the rights of suspects or defendants before carrying out criminal proceedings, but law enforcement officials tend to avoid this. There are many ways

${ }^{1}$ Pusat Pembinaan Pengembangan Bahasa, Kamus Besar Bahasa Indonesia, Cet. Ketiga, Balai Pustaka, Jakarta, 1990, p. 770.

${ }^{2}$ M. Yahya Harahap, Pembahasan Permasalahan dan Penerapan KUHAP Penyidikan dan Penuntutan, Edisi 2, Cet. Keempat, Sinar Grafika, Jakarta, 2002, p. 157.

${ }^{3}$ Ibid, p. 330 . 
that can be done, including not informing or fooling a suspect or defendant, that is, notifying but accompanied by threats or unsympathetic attitudes, or notifying but accompanied by information that is subtle but biased.

Rights basically contain elements of protection, interests and will. According to the famous Effendi, rights are relative and absolute, as individuals, they have personal rights (personal rights) and turn into human rights (human rights) when among each other struggling in a life together.

The notion of human rights actually covers a broad spectrum and wrestles dynamically from individual human rights to communal human rights. The conflict with the application of human rights is caused by differences in the views of human rights that are desired, there are two opinions about human rights, namely translating the term government requires emphasis on individual human rights, while the government uses human rights enforcement with communal tend to be authoritarian.

Human rights are essentially natural rights inherently inherent in every human being from birth. Actually, human rights do not require juridical legitimacy for their treatment in a national or international legal system, although there is no constitutional protection and guarantee for human rights, that right still exists in every human being. The theistic idea of human rights according to Salman Luthan, is acknowledged as the most essential value in human life. However, because most human life systems are secular and positivistic, the existence of human rights requires a legal basis to be put in place in regulating human life.

The understanding of human rights adopted in Indonesia is a set of rights inherent in the nature and existence of humans as God's creatures and is a gift that must be respected, upheld and protected by the state, law, government, and everyone for the sake of honor and protection human dignity and dignity.

According to Baharuddin Lopa, human rights basically consist of two basic rights, the most fundamental, is the right of equality and the right of freedom. It is from these two basic rights that other human rights will be born, or without these two basic rights other human rights will be difficult to uphold.

Based on the description above, human rights in essence contain two faces, namely human rights in the sense of human rights (human rights) and human rights in terms of community rights, these are two aspects that are characteristic and at the same time legal identity, namely aspects of humanity and social aspects. Criminal procedural law is needed if there is a suspicion that someone has violated the prohibitions of criminal law, and criminal procedural law is not only to officially determine the existence of violations that have been unofficially known to people, but also to carry out actions when there is a suspicion that there is a criminal act committed. Based on this, the function of criminal procedural law is to carry out the provisions and seek material truth, that is the real truth.

The guarantee of human rights protection in criminal procedural law has an important meaning, because most of the series of criminal procedural proceedings lead to human rights restrictions such as arrest, detention, search, confiscation and punishment. This affirmation is contained in the general explanation of the Criminal Procedure Code, which regulates the protection of human dignity and dignity.

In connection with the issues raised by the author, the applicable Legal Protection Forms as regulated in the Criminal Procedure Code (Criminal Procedure Code) are as follows:

1. The Criminal Procedure Code provides several protections for suspects, defendants and convicts relating to human rights. However, these rights in practice are not necessarily given by law enforcement officers. Though the main key of a criminal justice system process is the action of the police as an investigator. Therefore, the efforts made by the accused were wrongly arrested relating to the defendant's rights in this research case, including:

a. personally choose a legal advisor as a defense attorney,

b. make a defense, such as a request that the defendant be free by law,

c. request for change of panel of judges and objections to continue the trial.

d. Another effort is to submit a request for the suspension of detention and defend yourself against the indictment of the public prosecutor.

2. Not all efforts made by the defendant or his legal counsel were granted. Because the efforts made are not in accordance with applicable law, such as a defense by requesting a change of judges. The reason for the submission was the judge's subjectivity in examining and adjudicating the case. Replacement of judges can be done if they meet the elements in Article 157 Criminal Procedure Code and Article 29 paragraph (3), (4) and paragraph (5) of Law No. 4 of 2004. Article 157 KUHAP paragraph (1) a judge is obliged to resign from adjudicating from a particular case if he is bound by blood relations to a third degree, husband or wife relationship although divorced from the presiding judge, one of the member judges, public prosecutor and clerk. Paragraph (2) The presiding judge, member judge, public prosecutor or clerk is obliged to resign from handling the case if he is bound by blood relations or marriage relationship to the third degree of husband or wife relationship even though he is divorced with the defendant or with legal counsel. 
Article 29 paragraph (3) A judge is obliged to resign from a trial if he is bound by blood relations or marriage relationship to the third degree, or a husband or wife relationship despite being divorced, with the chairman, one of the judge members, prosecutors, advocates, or clerks. Paragraph (4) Chairperson of the panel of judges, member judges, prosecutors or clerks shall be obliged to resign from the trial if they are tied to blood relations or marriage to third degree, or husband or wife relations even though they have been divorced from the party on trial or advocate. Paragraph (5) A judge or clerk is required to resign from a trial if he has a direct or indirect interest in the case being examined, both of his own volition and at the request of the litigant.

These elements are related to blood relations or marriage to third degree with the defendant or legal counsel, and there is a direct or indirect interest in the case being examined, both at their own volition and at the request of the litigant. Based on the above, the replacement of the panel of judges proposed by the defendant's legal counsel cannot be carried out, because the elements in Article 157 Criminal Procedure Article 29 paragraphs (3), (4) and paragraph (5) of Law no. 4 of 2004 was not fulfilled, on this basis the replacement of the panel of judges was unacceptable.

1. Legal assistance in the criminal justice process is one of the rights guaranteed in the Criminal Procedure Code. Pursuant to Article 54 of the Criminal Procedure Code confirms that the suspect or defendant is entitled to obtain legal assistance at every level of examination. However, this provision is facultative, because even without an advocate accompanying the suspect or defendant, the examination can continue. Pursuant to Article 56 of the Criminal Procedure Code, if the suspicion or indictment of a suspect or defendant is threatened with a death sentence and / or fifteen years or more or specifically for those who cannot afford it if a criminal offense is threatened with a sentence of five years or more and he does not have legal counsel.

2. Juridical and Sociological Implications of the Defendant Who Was Wrongly Arrested in the Misguided Criminal Justice Process In the criminal justice process, there is one principle that the judge must not abandon as a law enforcement officer in a trial, that is, the judge must not refuse a case that has been submitted to obtain a decision and trial process that has entered the material subject, then it must proceed to the process proof. The legal basis for a judge in continuing the criminal case process has been regulated in Article 16 paragraph (1) of Law no. 4 of 2004, Article 156 paragraph (2) of the Criminal Procedure Code and Article 144 of the Criminal Procedure Code relating to amendment of an indictment. Based on this, what is done by the judge is in accordance with applicable regulations, namely in accordance with Article 16 paragraph (1) of Law no. 4 of 2004, Article 156 paragraph (2) of the Criminal Procedure Code and Article 144 of the Criminal Procedure Code, because the indictments filed by the public prosecutor have passed the determination of the trial day, so that alteration and termination of the trial process cannot be carried out. However, the trial process does not merely proceed just like that, but also pay attention to the human rights of the accused as a human being. In Article 16 paragraph (1) of Law No. 4 of 2004 reads: the court must not refuse to examine, try, and decide on a case filed under the pretext that the law does not exist or is unclear, but it is obligatory to examine and try it. Article 156 paragraph (2) of the Criminal Procedure Code, if the judge expresses an objection (which is submitted by the defendant or his legal advisor), then the case is not examined further, on the contrary if it is not accepted or the judge is of the opinion that it can only be decided after the examination has been completed, then the trial next. And in Article 144 paragraph (1) of the Criminal Procedure Code,

3. the public prosecutor may amend the indictment before the court determines the hearing day either with a view to perfecting or not continuing the prosecution. Paragraph (2) The amendment to the indictment can be done only once no later than seven days before the trial begins. As for what the judges can do is square off to suspend the detention of the defendant, as explained by Kartijono in one of the strong trial processes allegedly after the wrong arrest: "if the results of DNA testing conducted by the Lab. Polri's forensics are brought to our court table, so we will plan to hold a detention postponement, of course, with certain conditions, because we are back to the rules ".

Based on the description, a fair and proper justice principle (due process) has been applied which refers to the important treatments of the examination process carried out through formal rules, this is done to provide guarantees for the rights of each individual. The hope of all parties to the existence of a criminal examination is the fact that it is revealed, the rules that apply, the situation during the trial process and the judge's decision, which ultimately points to the defendant guilty or not.

The disclosure of the wrongful arrest of the defendant at this stage of adjudication has legal and sociological or problematic implications for some circles and the defendant himself, including: 


\section{Juridical Implications for Defendants of Wrong Procedure}

According to Mudzakkir: "Prosecutors and judges are allowed to make legal innovations by informing the defendant's rights as a result of a proven innocent process for direct inclusion of compensation in the judge's decision, if approved then should be given together with the decision because the process is final not pretrial again ". The impact obtained by the defendant in the trial process was a wrong procedure which included:

a. First, it still applies the principle of presumption of innocence. The interpretation of the presumption of innocence cannot be interpreted in letterlijk, because if interpreted so (letterlijk) then the task of the police will not work. Therefore, the logical consequence of the principle of presumption of innocence is that the rights of the suspect and the defendant as human beings are given.

b. Second, immediately obtain legal certainty (guilty or innocent). If not proven guilty, the verdict handed down by the judge is free from all indictments by the public prosecutor (vrijspraak), or at least releases the defendant from all lawsuits (onstlag van alle rechtvervolging).

c. Third, you can avoid the principle of nebis in idem, because you have obtained legal certainty. Fourth, with the existence of legal certainty, the defendant is wrongly arrested and his family can file compensation for the arrest of the person. The form of compensation is only material and the acquisition is very minimal. If in the evidentiary process it turns out that the evidence states that the defendant is not proven guilty of committing a crime and is most likely to be free, then the public prosecutor should automatically inquire in advance about the suspect's right to obtain compensation, so that compensation immediately gets clarity. This action was taken to safeguard the feelings of the defendant, because the criminal case that was charged caused harm to the defendant.

d. 2. The Sociological Implications of Wrong Catch (Wrong Procedure) in the Association of Indonesian Communities Sociologically, the implication of the error due to the criminal justice system against the defendant is defamation of the defendant, because he was labeled as a suspect and the defendant is a criminal act of murder. While the implication for the community is the public's distrust of the criminal justice system, this is indicated by the noise of visitors to the trial that occurred during the trial process. As for what the community did towards the trial process was to make the trial situation not conducive. The Criminal Procedure Code has regulated the rehabilitation as a result of the mistakes of the criminal justice sub system. Based on Article 97 of the Criminal Procedure Code, the defendant who has been declared not guilty and has received a free decision from the judge is entitled to rehabilitation. Provision of rehabilitation is only limited to the statement at the court hearing that is included in the defendant's acquittal. From the description it can be seen that, there are already rules regarding the restoration of good name due to the error of law enforcement actions, but the rehabilitation is only limited to the scope of the trial.

ICCPR (International Convenant on Civil and Political Rights) as an international convention which has now become a positive law in Indonesia has many similarities with the Criminal Procedure Code, namely the various provisions on the rights of the defendants regulated in the ICCPR have been accommodated in the Criminal Procedure Code. However, it appears that as a criminal justice system, the Criminal Procedure Code is not yet complete and does not yet reflect an integrated system of regulation. There are still many protections for the rights of the defendant that have not yet been regulated in the Criminal Procedure Code. Like a number of human rights the defendant was not even regulated as a right, but was applied as a guideline for the administration of justice. This causes differences in perceptions between law enforcers, especially investigators and public prosecutors who consider the provisions unnecessary because the provisions only regulate justice. In line with the ICCPR (International Convenant on Civil and Political Rights), the principle of presumption of innocence must be interpreted, that a suspect or defendant in undergoing a criminal justice process, in order to be given full legal rights as detailed in the convention. Thus, the protection of the principle of presumption of innocence has been completed by law enforcement agencies. The court ruling which states a defendant is guilty based on evidence that does not doubt the panel of judges, must be interpreted as the end of the legal protection of the defendant's right to be considered innocent. In connection with the implementation of positive legal instruments, there is a weakness of the Criminal Procedure Code in terms of compensation, which is a complicated and long procedure. Based on absolute theory, every decision of acquittal is always followed by the award of compensation, it is not seen whether there is an illegal detention made or gross (gross bond) of the official or not. Absolute theory explains that, the decision to release only gives a person the right, if an illegal arrest or detention has been carried out on him by the official who made the arrest or detention. The law always states that if there are rights that are violated, then there must be the possibility to sue and obtain them (yam jus ibi remedium).

The implementation of the criminal justice system can be said to be good if it is carried out in accordance with the mandate of the Act and is accompanied by high morale from law enforcers. Regarding the 
professionalism of law enforcement officers in the criminal justice system one of the obstacles is the facilities and infrastructure such as budgetary issues. Based on this, the criminal justice process needed to advance are:

a. qualified apparatuses, thus increasing human resources is needed;

b. the costs for the police to handle a case need to be considered in order to be sufficient.

\section{E. Conclusion}

From what has been described in the description above, the writer can conclude as follows, namely:

1. Legal protection given to the accused is an indication of wrongful arrest is treated the same as other defendants that is given their rights under the Criminal Procedure Code. This was done because it prioritized legal certainty, namely by the existence of an innocent verdict from the court, the decision could be used as the basis for the right to file compensation claims. Legal protection relating to the rights of the accused has been regulated in international conventions and legislation, but its implementation needs to be emphasized, so that investigators in carrying out their duties are more professional.

2. Legally and sociologically, citizens who have experienced wrongful arrests (wrong procedures) will still be protected by their rights, as stipulated in the ICCPR (International Convenant on Civil and Political Rights), in which case Indonesia has ratified and has ratified regulated in the Criminal Procedure Code, and strengthened by further legislation.

\section{References}

Agus Raharjo, 2008. Mediasi Sebagai Basis Dalam Penyelesaian Perkara Pidana, Jurnal Mimbar Hukum, Vol. 20 No. 1, Februari, FH UGM, Yogyakarta. Bandung.

Al. Wisnubroto dan G. Widiartana, 2005, Pembaharuan Hukum Acara Pidana, Citra Aditya Bakti, Jakarta.

Amiruddin dan Zainal Asikin, 2004, Pengantar Metode Penelitian Hukum, Raja Grafindo Persada,

Anthon F. Susanto, 2004, Wajah Peradilan Kita, Konstruksi Sosial Tentang Penyimpangan, Mekanisme Kontrol dan Akuntabilitas Peradilan Pidana, Cet. Pertama, Refika Aditama, Bandung.

Bambang Sutiyoso, Perkembangan dan Penegakan Hak Asasi Manusia (HAM) di Indonesia, Jurnal Media Hukum Vol. 15 No. 1, Juni 2008.

Barda Nawawi Arief, 2005, Bunga Rampai Kebijakan Hukum Pidana, cet. Ketiga Edisi Revisi, Citra Aditya Bakti.

Riyanto Adi, 2004. Metodologi Penelitian Sosial dan Hukum, Granit, Jakarta.

Soerjono Soekanto dan Sri Mamudji, 2007, Penelitian Hukum Normatif Suatu Tinjauan Singkat, Edisi. Pertama, Raja Grafindo Persada, Jakarta.

Pusat Pembinaan Pengembangan Bahasa, 1990, Kamus Besar Bahasa Indonesia, Cet. Ketiga, Balai Pustaka, Jakarta.

Masyhur Effendi dan Taufani S. Evandri, 2007, HAM dalam Dimensi/ Dinamika Yuridis, Sosial, Politik, dan Proses Penyusunan/ Aplikasi Ha- kham (Hukum Hak Asasi Manusia) dalam Masyarakat, Cet. Pertama, Edisi Revisi, Ghalia Indonesia, Bogor.

Moh. Mahfud MD, 1999, Pergulatan Politik dan Hukum di Indonesia, Gama Media, Yogyakarta.

M. Sofyan Lubis dan M. Haryanto, 2008, Pelanggaran Miranda Rule dalam Praktek Peradilan di Indonesia, Juxtapose, Yogyakarta.

M. Yahya Harahap, 2002, Pembahasan Permasalahan dan Penerapan KUHAP Penyidikan dan Penuntutan, Edisi 2, Cet. Keempat, Sinar Grafika, Jakarta.

Soeharto, 2007, Perlindungan Hak Tersangka, Terdakwa, dan Korban Tindak Pidana Terorisme, cet. Pertama, Refika Aditama, Bandung.

Supriyadi, Pelanggaran Hak Asasi Manusia Dalam Penyidikan Perkara Pidana, Mimbar Hukum No. 31/ VIII/ 1998. 